\title{
ANALYSIS OF BATHING HABITS AMONG SPA VISITORS
}

\author{
Katalin Lövei-Kalmár ${ }^{1}$, Tímea Jeles ${ }^{2}$, Gergely Ráthonyi ${ }^{3}$ \\ ${ }^{1}$ kalmar.katalin@foh.unideb.hu \\ 2timeajeles@gmail.com \\ ${ }^{3}$ rathonyi.gergely@econ.unideb.hu
}

${ }^{1}$ University of Debrecen, Faculty of Health, 2-4. Sóstói str. Nyíregyháza

${ }^{2}$ University of Debrecen, Faculty of Health, 2-4. Sóstói str. Nyíregyháza

${ }^{3}$ University of Debrecen, Faculty of Economics and Business, 138. Böszörményi str. Debrecen

\begin{abstract}
The valorisation of healthy lifestyle has indicated the dynamic increase of healthcare sector. The consumer behaviour has been forming deterministically in health tourism. Visitors of spa towns can select various combinations of services either to sustain their health, to rest, to relax or to recover. It has a great importance for spas offering complex health tourism services to know the demands of guests and to reach the target groups with special, personalized service packages. After considering the statistical indicators of tourists visiting the spas of Northern Great Plain Region and the competitors of a selected spa, this paper aims to investigate the coherence among bathing habits, influencing factors of service demands, age and non-motivating coherences. The survey was taken place in a selected spa in Hajdú-Bihar County in August 2018 with random sampling questionnaire involving 256 visitors. During data analysis the coherence among indicators was examined with variant analysis (Levene's test), in case of significant result with Welch's t-test. Variances in age groups were analysed with Tamhane's and LSD tests (post hoc analyses). We concluded that the primary information source of spas is still the suggestion of friends, acquaintances independently of the age of the respondent. Knowing this is relevant for further marketing communication. The most important features among the respondents are the condition of the spa and cleanness which are the basics of quality services. Motivations with coherence to age are social life and gaining experience, recovery and disease prevention. Visitors have the largest interest for family and kid programs. Recognition of bathing habits helps in marketing communication, reaching target markets effectively, pricing and service developments as well.
\end{abstract}

Keywords: health tourism, spa, motivation, spa services

(JEL Classification: Z32) 


\section{INTRODUCTION}

Hungary, thanks to its geothermal characteristics, has unique thermal water resources (quality and quantity) considering either Europe or worldwide. $80 \%$ of its area covers thermal and healing water resources (GÁSPÁR, 2009). However, in Japan and Iceland the temperature of thermal waters are higher but with low mineral content, in Italy and France the temperature is lower, the mineral content is high, in Hungary thermal waters with high mineral content can be found. Hungary is rich in other healing factors as well: next to 5 healing caves and 1 healing mofetta, thousands of thermal springs operate, the number of qualified healing water wells is near to 250 and the number of qualified baths is over 70 . Based on its location, the Northern Great Plain Region is the richest in qualified healing factors, 2 from 5 qualified healing mud deposits are located in the region (Tiszasüly and Hajdúszoboszló) (ÖTM, 2007). During the competition for tourists the innovative marketing tool of spa towns is the development and improvement of services based on knowing the demands of visitors. Accordingly, it is important to explore bathing habits as it was done in the selected spa in Hajdú-Bihar County.

\section{Formation of bathing culture in Hungary}

Today's bathing culture is determined by several historical periods. In history, when the Roman Tiberius Nero conquered Pannonia and established the first settlement at the area of today's Budapest, set the Roman bathing culture in Hungary by using its rich thermal water resources (BEDE, 2014). In the Roman Empire bathing was a part of daily life. The archaeological explorations in Budapest revealed 18 military and civil baths until now, but ruins of Roman baths can be found in other Transdanubian cities such as Tata or Balf. The excessive moral notion of the middle age affected the forming of bathing culture negatively. Bathing was strictly forbidden because of the lightly clad dressing. From 1178, Johannian knights established several hospitals in Buda and used thermal water for curing. Following Turkish rule, bathing culture of Middle-East was introduced in Hungary, indicated a new golden age of bathing. Turkish baths built on healing water formed special style and social bathing culture. Several written and material relics endured from the developed bath-life of Buda, Esztergom and Eger (CSEKE, 1982). In Buda and Eger Turkish baths are still operating which is unique in whole Europe.

Healing bathing with scientific basics started to form in the XVI. Century in Europe. After the end of the Turkish era, in the XVII. Century European bathing habits started to nationalize in Hungary, several bath centres were formed countrywide. The healing water of Balatonfüred started to be well-known, baths were built in Hévíz and Parád, the bath of Balf was established (BOROS et al., 2013). There was a boost in the bathing culture of Budapest in the second half of the XIX. Century. After the reconciliation the Hungarian baths were surveyed and qualified. As a result of the survey, several baths were recovered and rebuilt in this period. In the XIX. Century balneotherapy had a great role in curing, since effective procedures, medications and operation techniques were not available. In 1837 the Commission of Balneology of the Budapest Royal Medical Association was formed. The main task of the Commission was to survey the baths of Hungary, but the propagation of baths was also a crucial goal. The 1st World War meant a large decrease in the life of baths in the countryside, but after its end - thanks to the uniform and reasoned bath politics - especially the baths of Pest and the offered services were improved. The Hungarian balneotherapy had international reputation in those days (BENDER, 2014). After the 2nd World War Hungarian baths had exclusive position considering the number of tourists again. Next to the baths that offer traditional health tourism services, spas with quality services have appeared. In the frame of the Széchenyi Plan, in 2000 health tourism development has started countrywide, in which spas and baths had a specific role (MICHALKÓ and RÁCZ, 2011).

The bathing culture of Hungary has its umpteenth flourish in these days. Next to the traditional thermal baths and several wellness spas were built, the number of spas increased and the number of offered services expanded. In 2013 the number of thermal wells were above 1300 and the number of healing water wells was more than 250 (BEDE, 2014). Budapest is the only metropolis in the World where the number of thermal springs is larger than 100 and there are more than 50 operating baths. In 2017, there were 529 baths in Hungary (380 with permanent operation, 149 with seasonal operation).

\section{Trends of health tourism}

The needs and requirements of every tourism participant change over time depending on their health condition. Till the end of the XX. Century, parallel with the innovation of medical science, the term of health tourism has transformed as well. Health tourism involves all travel activities connected to health. Spa tourism represents a special form of convalescence with emphasis on health and preventive care. The development of spa tourism is preconditioned by the existence of natural healing resources that affect the focus of spa treatment. (VILDOVA at all, 2015) In Hungary two main areas are separated, healing tourism with the aim of therapy; and wellness tourism (SZIVA, 2010). Classical healing tourism evolved in the XIX. Century. The main goal of healing tourism is to cure the actual disease. The primer motivation of tourists is to improve their health condition. Classical healing tourism is based on natural healing factors (healing water or healing climate), this requirement still can be found on demand-side. Although, today there are available healing establishments that do not have natural healing factors (KÖNYVES et al., 2013). The 
establishments of health tourism offer healing, medical and touristic services as well. The target group of traditional healing tourism is the age group of society above 60 . Tourists targeting healing services can be characterized with longer stay comparing with average tourists, because healing treatments as a cure may last for weeks. Healing tourism is concentrated to qualified baths (MTÜ, 2018). A consumer of health tourism can be under 36 years as well, however they refuse or do not respect the natural healing treatments comparing with older age groups. The other trend is wellness, which is interpreted in several ways in Europe, but each definition contains identification with health. Wellness is no other than a life philosophy that is prevailed in daily life (GYÖRI et al, 2013) The definition of wellness is based on 4 principles: regular exercises, healthy eating based on scientific background, improving psychical condition and sustainable living. Today's wellness tendencies are characterised by gaining experience and personalised services. Consumers of wellness tourism are mostly following the rules of healthy lifestyle. However, wellness tourists stay short time, mainly for a weekend, but using high quality services, especially related to demands for self-realization. Kid- and family-friendly services have a great importance in this consumer sector.

The main aspect of traditional baths was treating diseases - which means that healing is in foreground and prevention is in the background. Visiting baths is part of our daily life, not just only a place for vacation or healing. The new generation, characterised with health-centric behaviour, indicated the expansion of offered services that united relaxing, resting and health maintenance. To propagate the using of baths it is worth to emphasise the turn back to natural healing methods (PINTÉR, 2013). A part of the medical doctors argue with the efficiency of complementary medicina, as well as the efficiency of cures with healing water, which means that the research to certify the effects of healing water is important.

During the last decades wellness orientation has strengthened in Europe. The classic European baths put efforts to sustain their competitiveness, accordingly, to form new image and appear as wellness destinations focusing on relaxing (MICHALKÓ and RÁCZ, 2011). The market of health tourism dynamically grows and diverges many directions adapted to consumer demands. Although, the service providers of Hungary have mainly regional or local importance because the portfolio of offered services does not meet with the requirements of tourists from abroad (KÖNYVES et al., 2013).

The future of Hungarian baths lies in the harmonized use of modern medical science and novel bathing culture. Continuous service and product development is needed to meet with market conditions and demands. Continuous increase of demand should be considered in parallel with complex and quality services (SZABÓ, 2015). Furthermore, developments should be in line with the demands of new and under 36 years target groups:

- these groups primarily use fitness and wellness ser- vices.

- Visit of families with small children aims spa experience.

- Middle age groups visit for health sustain and prevention.

The largest consumers of classical health tourism are still the older age groups, furthermore, their role will be more emphasized because of the aging society of European countries. (Aquaprofit 2007)

\section{Health tourism of Northern Great Plain Region}

Considering social and economic aspects, the Northern Great Plain Region is one of the most underdeveloped regions of Hungary with the lowest GDP. The touristic competitiveness of the area is significantly determined by the infrastructure level of the region (KSH, 2017). The most important natural formations of the Region are the thermal water springs, the River Tisza, the Lake Tisza and Hortobágy. Health tourism of the Region is based on the quantity of water resources and their mineral content (MÜLLER and KÖNYVES 2006). The available touristic products of the Region are health tourism, green tourism, program tourism and rural tourism. The largest touristic value of the area is the thermal water which is used mainly by Hajdú-Bihar County. In the last century thanks to Ferenc Pávai-Vajna for the exploration of several significant thermal waters and thermal baths (Szeged, Hajdúszoboszló, Karcag, Debrecen, Szolnok). The County has 3 qualified healing locations, for example Hajdúszoboszló, Debrecen and Hajdúnánás. Considering health tourism the Region shows great concentration because touristic performance of Hajdúszoboszló has international importance and has a great role in the national tourism as well.

The capacity of Hungarian baths is 860803 capita. In national level, the Northern Great Plain Region is at the third place after Western Transdanubia (20\%) and Central Hungary. The capacity of the Region is $18 \%$ of the national level (152 476 capita).

Based on the data of the Hungarian Central Statistical Office in 2017 there were 529 registered baths and spas in Hungary, 77 in the Northern Great Plain Region (60 with permanent operation, 17 with seasonal operation). In Hajdú-Bihar County there are 26 baths with permanent operation and 5 with seasonal use. The baths of the Region are focusing on healing services, most of the baths have thermal or healing pool, but underwater water-massage, medical massage and underwater physical therapy are common services too (MEZÖ and KOVÁCS, 2013). Massage and sauna are the most common elements of wellness services. Rural catering is the most common service connected to gastronomy, and beach soccer and beach volleyball considering sport services. According to the popularity of wellness tourism the Region need development regarding to wellness, gastronomy and sport services as well. 
Figure 1: Offered services in the baths of the Northern Great Plain Region 2017 (no.)
Szatmár-Bereg County and Jász-Nagykun-Szolnok County bathing services give the largest rate of income and

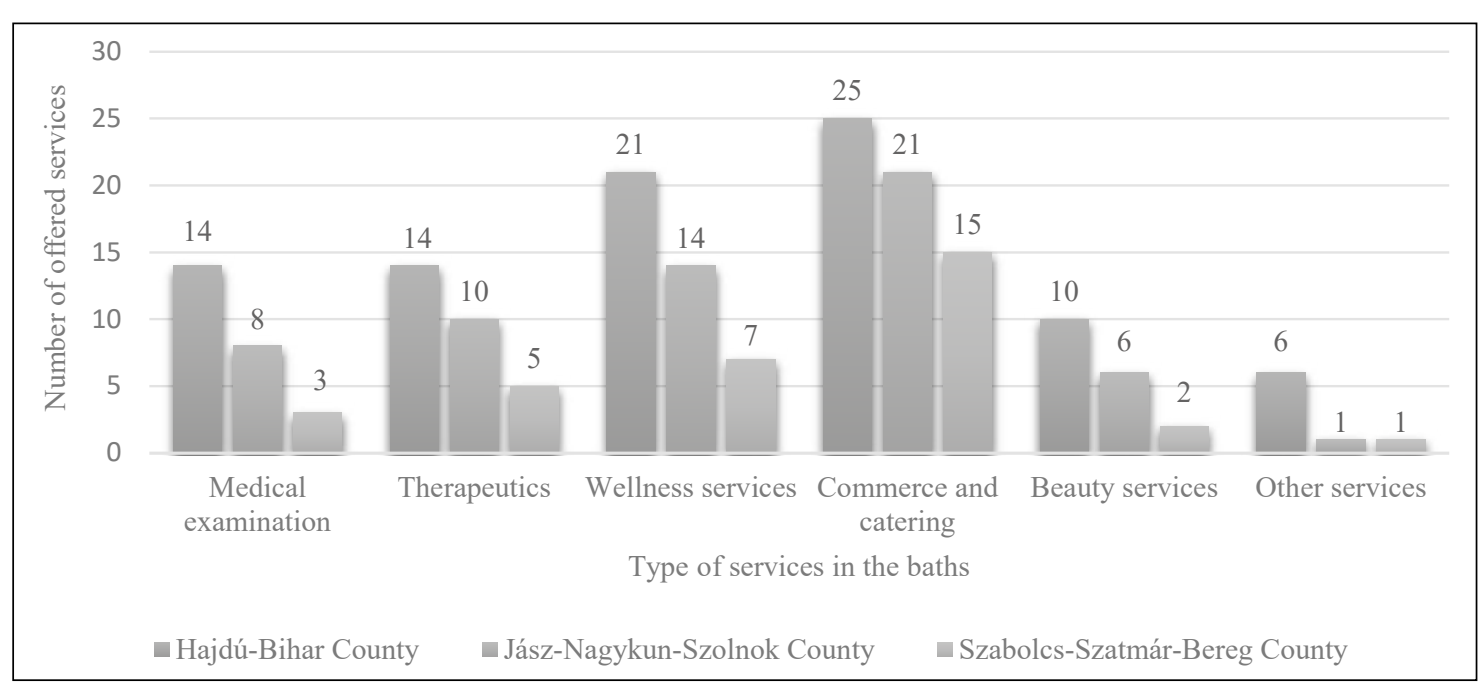

accommodation the second. Healing and health $\mathrm{m}$ a in $\mathrm{ten}$ a nce service result the smallest rate of income in every three county of the Region.

The number of visitors between 2010 and 2017 is demonstrated in the figure 2 in territorial breakdown:

In 2017, from the 31 baths of Hajdú-Bihar County, 14 baths offer healing treatments, health maintaining wellness services can be used in 21 baths. Commerce and catering are the most common services. In all the three counties of the region wellness service can be found in more spas than healing treatment. Medical examination is connected to healing treatments as a service, due so, most baths offering balneotherapy treatments supported by societal insurance. Beauty services (e.g. manicure, pedicure, solarium, fitness services) are the least common services of baths in the Northern

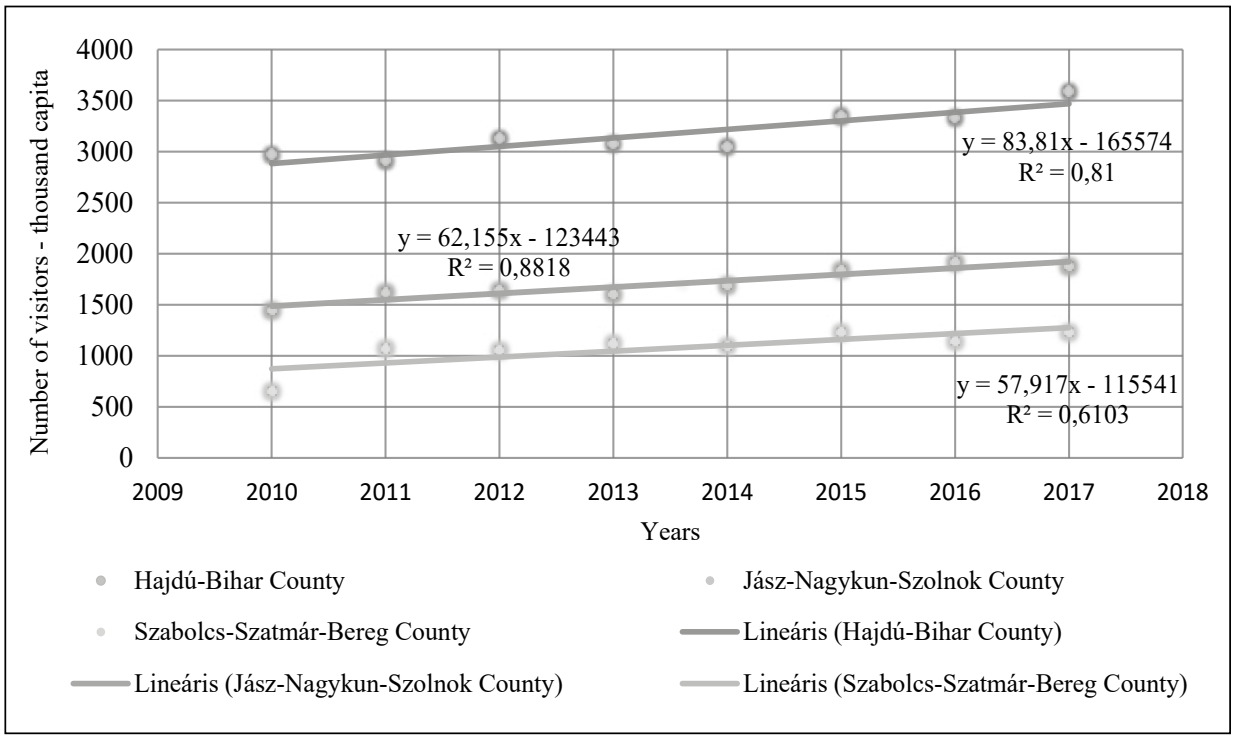

Source: KSH; own edit

Each point of the diagram represents an observation unit, accordingly, represents the number of visitors annually. From the three considered county, Szabolcs-Szatmár-Bereg County produced the lowest number of visitors (1228 thousand capita in 2017). In Jász-Nagykun-Szolnok County the number of visitors was over 1500 already in 2010. As the figure shows, the number of guests in Szabolcs-Szatmár Bereg and JászNagykun-Szolnok Counties was altogether less than in HajdúBihar County, which resulted 3000 thousand capita in 2010, and more than 3500 thousand capita in 2017. There is a slight increase in the number of guests from 2010 in the Region, which is demonstrated with the fitted linear trend function as well. The R2 value shows a strong relationship between the examined indices, either in Jász-Nagykun-Szolnok or 
Hajdú-Bihar County there is a strong coherence between the trend line and the point diagram, so the trend line can be used as a predictive function for the next period. Considering the equations of the linear trend lines we can conclude that the increase is the most dynamic in Hajdú-Bihar County (slope $=83,81)$.

The Northern Great Plain Region and Hajdú-Bihar County have a great national importance considering the offered services of baths, especially healing and thermal baths. The capacity of the Region is $18 \%$ of the national level (152 476 capita).

In Hajdú-Bihar County in 2017 there were 31 operating baths. The mostly offered services are commerce and catering, and there are 14 baths where healing services are offered. Health maintenance wellness services can be found in 21 baths. The large number of baths for the relatively small geographical area of the Region indicates intensive competition for visitors. The selected spa - that offers general bath services, healing treatments, wellness services, accommodation, leisure and beauty services - must also do well in this competition.

The selected spa has 2 indoor and 7 outdoor pools. The total water surface of the pools is 2520 square metre. Among the outdoor pools there are a study pool, a study pool with slide, a dabbling pool, 2 thermal pools, a fun pool and a waveless sport pool. The healing section has been fully renovated in 2011 . The full range of societal insurance supported services can be selected in the spa. The total capacity of the healing section is 34 capita. A medical doctor specialised in rheumatology expects patients from Monday to Thursday every week. The doctor gives medical examination without referral and treatments in place.

Considering wellness services there is a complex sauna park available with steam cabin, infra sauna, 2 Finnish sauna and cold/warm sinking pool. Chocolate massage, lava stone massage and sport massage are also available. Available kid friendly and leisure services are tennis, beach soccer and beach volleyball fields. Pedicure is offered as beauty service at the spa.

Program tourism is a deterministic part of the city's services. During main season the spa offers several programs to the visiting guests. In June, July and August there are full-day events with night bathing. The square in front of the building offers local, regional and national events for the tourists.

\section{MATERIAL AND METHODS}

The demand for health tourism increases dynamically and develops to several directions according to consumer habits. The demands of guests can be fulfilled if motivations of traveling, information collecting practices and bathing habits are known. To get a wider view of these issues a questionnaire survey was taken place in the selected spa in August, 2018. Sampling was a simple, random sampling, because every guest had the same chance to be involved in the probe. In total, 262 visitor were involved. The questionnaire contained 17 simple and multiple answer questions. For 4 question a 5 range scale was used according to importance (5-very important; 1-not important at all). The aim of the survey was to evaluate bathing habits and the relationship between age groups and motivation of bath selection. Accordingly, those results were highly considered, which showed the coherence between the motivation of visit, program and family- kid program selection depending on age.

The relationship between age groups and motivation was examined with variant analysis. If Levene's test showed significant result - which means variants in the groups were heterogeneous - the sample was tested towards with Welch's t-test (FALUS and OLLÉ, 2000). Differences among variants were tested with Tamhane's test during post hoc analysis, while those groups that did not give significant results were tested with LSD test (REICZIGEL et al., 2014). Significance level was set at $\mathrm{p}<0.05$.

\section{RESULTS AND DISCUSSION}

\section{Demographic characteristics of the sample}

Considering the socio-demographic characteristics of the questioned 262 guests, $85 \%$ of the respondents were female and only $15 \%$ were male. In our point of view, the rate of gender was affected by the differences in responding willingness between men and women but due to the inadequate ratio, we do not examine gender relations.

Taking highest graduation level into consideration we can say that $85 \%$ of the respondents have high school diploma or college/university diploma. $11 \%$ of the respondents finished a professional school and 3\% has primary school degree. 54\% of the respondents is a head-worker, $25 \%$ is physical worker and $21 \%$ is inactive. $50 \%$ of the resonders is between age $31-45$, $25 \%$ is between age $46-65,20 \%$ is between $18-30$. The smallest rate was above $65(3 \%)$ and under $18(2 \%)$.

$72 \%$ of the respondents - by its own admission - has average monthly income. Most of the respondents living in the same city where the spa is located and $29 \%$ lives closer than a 50 $\mathrm{km}$ radius. The closeness of the spa obviously affects their decision, but the large rate of local or regional respondents gives the conclusion that in spite of the main season the bath has a local/regional importance.

\section{Communication channels used by the guests}

The information needs and information gaining behaviour of today's consumers have deterministically changed. During planning marketing tools and to select the effective communication tools it is important to know the preferred communication channels of the guests. 34\% of the respondents selected the spa based on the suggestion of friends and acquaintance. This information channel is very important not just only because the guests who are satisfied and experienced come back again, but they share their experience with their friends and acquaintances and suggest the spa to visit (MÜLLER et. al. 2016). 20\% of the guests decisions based on his own experience - this is the second largest rate among the respondents - , satisfaction is important in this case as well. $16 \%$ of the respondents gained information before their visit through the website of the spa, $15 \%$ from social media, $10 \%$ from pages dealing with spas. 
Figure 3: Information sources about the spa (\%) $(\mathrm{N}=262)$

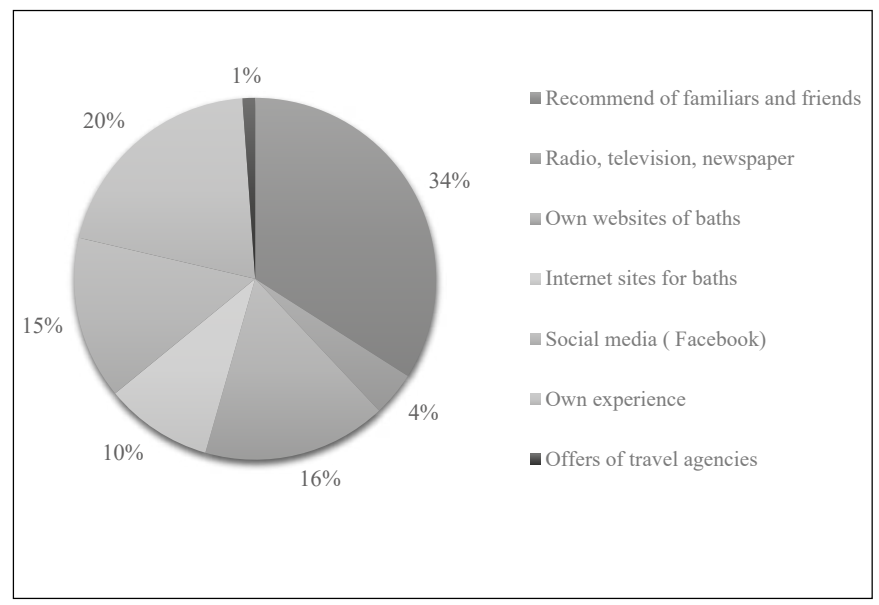

Source: own research, own edit

This means that $41 \%$ of the total respondents searching information on the internet because it is cheap and fast. Accordingly, it is important that the social media page and the website of the bath have up-to-date information. Television, radio, magazines and printed media has a low rate - there is no need to invest large amount of money to these communication channels.

\section{Duration and method of visit}

Among the respondents the bathing services are obviously popular. $45 \%$ of the respondents handle visiting the bath as a full day program. $40 \%$ of the respondents spend 3-5 hours average at the spa. Only $14.4 \%$ of the respondents spend less than 3 hours at the service provider. The smallest rate covers those visitors who spend less than 2 hours at the bath.

$93 \%$ of the respondents use the bathing services with company, meanwhile, $54 \%$ (largest rate) visits with family. $22 \%$ of the questioned guests arrives with consort or partner, $17 \%$ with friends or relatives. $7 \%$ of the sample is represented by guests who visit the bath alone. Due to a major part of the guests arrives with family, it is important to provide services for each age group. Services are liked to be used with company. The large rate of respondents visiting with family indicates that the spa is attractive for under 36 years age groups as well and it is possible to reach them effectively with adequate communication.

\section{Analysis of visiting motivation and its coherences}

Primarily, the respondents handle the visit as a family program but slightly the same motivations are gaining experience, the relaxing and resting too. Less deterministic motivation is selecting the spa as a place to spend free time based on connection to health, accordingly, either disease prevention or healing are less deterministic factors. The least motivating factor is sport (3.45\%) among the respondents.
Figure 4: Visiting motivation of guests (average) $(\mathrm{N}=\mathbf{2 6 2})$

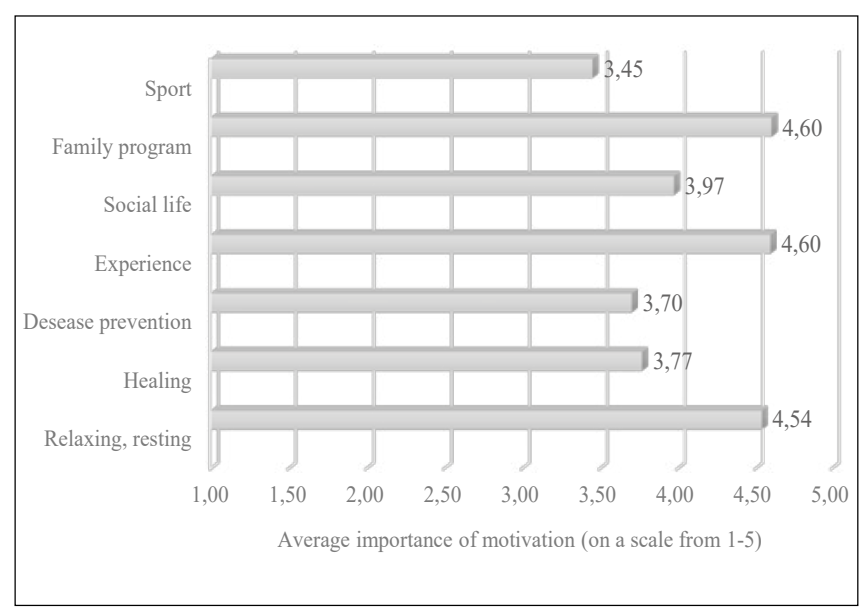

Source: own research, own edit

The primer goal of our research was to analyse visiting motivation, due so, to examine the coherence between motivation and age and gender. Our main aim was to recognize how age and gender affects the aim of spa visiting and find out if there is a relationship with the gender of the respondent. Accordingly, we used statistical calculations - as they are mentioned in the "Material and methods" section" - to analyse the sample.

\section{Motivation and age}

The demonstrated motivations on the figure above were examined related to under 18 , between 18 and 30, between 31 and 45 , between 46 and 65 and above 65 age groups. Significant difference, so coherence was found in case of healing, disease prevention, experience and social life motivations.

Healing and disease prevention were less motivating for age groups under 46 comparing with older visitors. This result, especially considering healing, is not surprising because the possibility of musculoskeletal disorders and arthritic disorders is higher at older age groups. By the spread of healthy lifestyle and the importance of disease prevention the conscious and preventive use of water recreation is expected in case of every age group. Although, until the appearance of disorders the preventive paradigm is not formed only in case of those age groups where these problems have greater possibility.

Gaining experience, as a bathing motivation showed significant difference in age groups between 18 and 45 . This result further than the own experience of the young and middle age visitors probably cohere with the experience of children - in case of visitors who arrive with family. This difference was not as deterministic among respondents above 46 .

The analysis of the coherence between social life and age gave an unexpected result because this motivation was evaluated significantly higher by age groups above 45 . Though, in case of older age groups it is more likely to visit the spa alone without company which indicates the need for social life as a deterministic motivation. 


\section{Analysis of bath selection affecting factors}

In the questionnaire we measured on a scale that which are those characteristics of the spa that are the most important for the visitors during destination selection (figure 5). The respondents identified the condition and cleannes of the spa as the most deterministic indicators which was followed by the helpfulness of the staff. It is important to mention other indicators as well, such as entrance fee (4.46), which was also a crucial issue that should be considered during development and marketing plans. Similar results have been confirmed by other Hungarian bathing researches (MÜLLER AND SZABÓ 2009, KERÉNYI et. al. 2009, MÜLLER 2018). This indicator is highlighted because it gives us the focus on the price-sensitiveness of the consumers. Less important factors are the availability of healing services (3.56) and the qualified healing location (3.59). This result may refer to the age group constitution and as it was seen it is not prefered motivation factor.

Figure 5: Bath selection affecting factors (average) $(\mathbf{N}=\mathbf{2 6 2})$

Source: own research, own edit

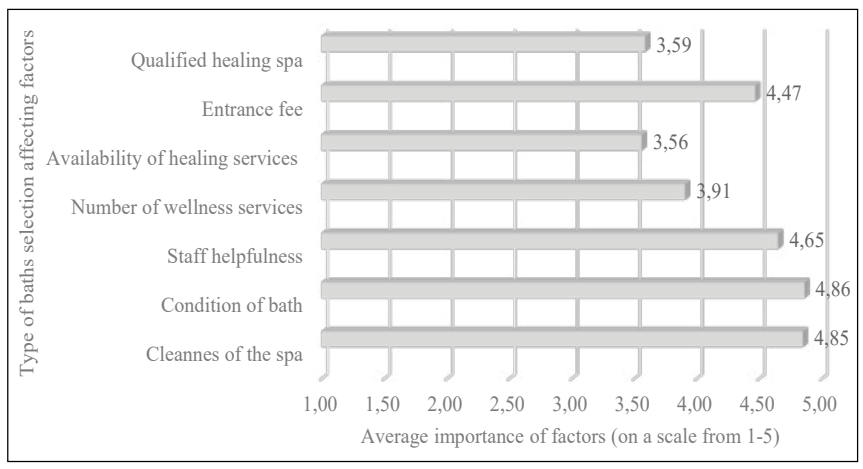

It was examined what other parameters and with what weight influence spa selection. The two most important indicators for the respondents were the adequate pool water temperature (4.64) and the nice environment of the spa (4.6). Furtherly, it was also important that the spa should not be too crowded (4.27) and children's pool and kid friendly services should be available (4.03). Nearby sights and programs (3.63) and swimming and sport possibilities (3.62) are less important for the visitors. Less deterministic aspect from the given answers is the number and variety of saunas (3.25).

Figure 6: Attractiveness of provided services, judgement of other decision affecting factors (average) $(\mathrm{N}=\mathbf{2 6 2})$

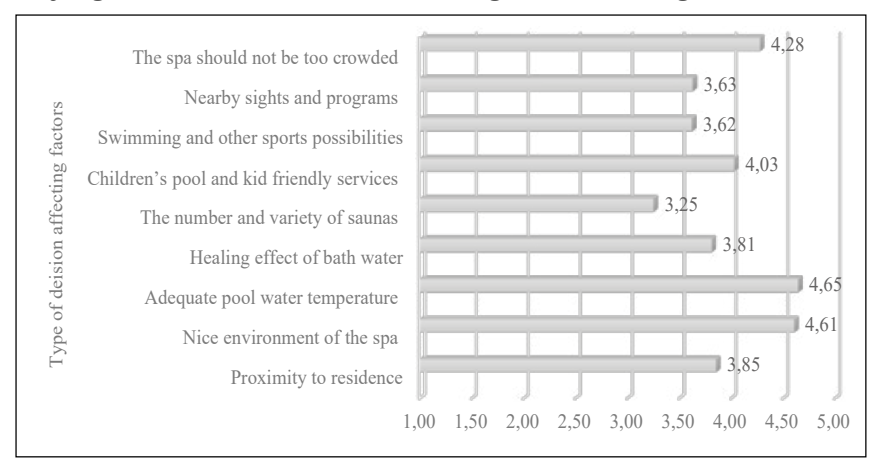

Source: own research, own edit
Considering the provided services we concluded that the most attractive from the actually operating 4 services is events for family and kids (3.88). Music events, concerts are moderately important in average, as the night bathing. The least attractive services are the sport programs. Meanwhile, family and kids events, music events and concerts and night bathing were not selected as "not important at all" by none of the respondents, nobody selected sport programs as the most attractive service.

Figure 7: Judgement of provided services (average and scatter) $(\mathrm{N}=\mathbf{2 6 2})$

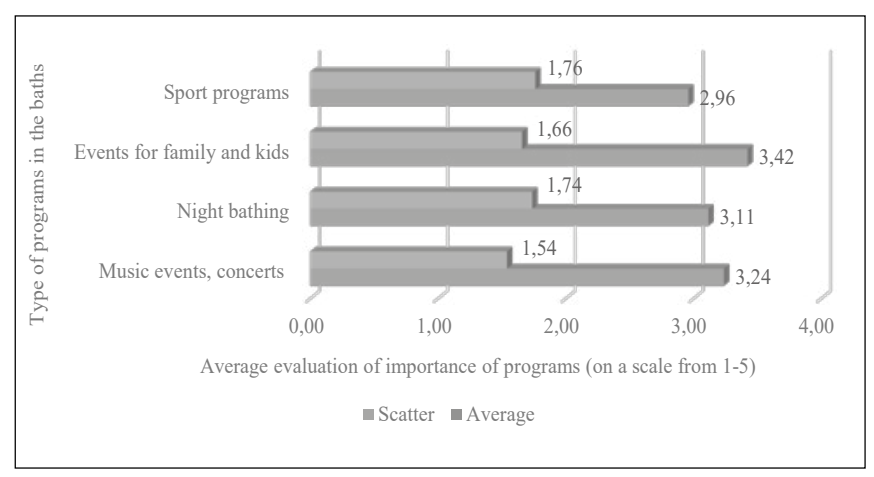

Source: own research, own edit

Though, the spa is planning to modify the range of offered programs, we were curious if the inquiry to night bathing and the age of respondents depend from each other or not. Based on the available data, by using variant analysis - Levene's test - we concluded that inquiry to night bathing depends on the age of respondents. 18-30 and 31-45 age groups resulted significant difference, so with Tamhane's post hoc analysis we arrived to the conclusion that night bathing is important for the mentioned two age groups, these age groups are obviously the target users of this service.

\section{FURTHER RESULTS CONSIDERING OFFERED SERVICES}

$46 \%$ of the 262 respondent uses sauna from the provided services, $37 \%$ uses massage services and $26 \%$ uses healing treatments. Accommodation is used at least by the respondents (7.6\%).

Based on the answers of the questioned guests, bathing services are used primarily, because less guests said yes to use other provided services during their residence.

As an open question we asked the respondents if there is a need for other service if the spa expand the provided services and involve new ones. From the listed 4 services (salt room, Jacuzzi, fitness room, Kneipp therapy) $55 \%$ of the respondents would prefer to use Jacuzzi. 51\% would use a salt room, 33\% would use Kneipp therapy and $21 \%$ would use a fitness room. Independently of the rates of answers, we can definitely say that there is a need for development and to broaden the provided services. 


\section{DISCUSSION}

The main goal of our research was to recognize the visitors' customer behaviour at the selected spa. Areas where information was gained from, information sources and communication channels were investigated and we concluded that the suggestion and advice of family, friend or acquaintance is still the most deterministic. Significant part of the respondents gain information about spas through the web, keyword based searching is used the most, webpages and social media are considered as authentic sources. Regarding to the target groups of the spa, communication should be focused on these sources and channels.

Main part of the respondents arrives with company, mostly with children or friends during the main season and considers spa visiting as a full day program. Accordingly, it is important to service experience for all age groups and offer services to fulfil the demands of each generation - independently if the spa is qualified or not. Among the asked guests the most important indicators of the spa - the deterministic basis of spa selection - are quality, cleanliness and the entrance fee. Due so, the most emphasised factor is observing hygienic rules, which appeared as an unexpected result. Nice environment, pool types, water temperature and the experience of using pools are important as well, but during development and improvement it is worth to examine their benefits and return, because during price determination the price sensitivity of guests must be considered. According to an assessment the results are the same: guests of the medicinal lake and spa of Hévíz considered tangible components important, they were ranked at the bottom of the importance order. (LÖKE at all, 2018)

By a survey in Thailand are spa goer-consumers focus on factors that influence the choice of the service spa including courteous service, prise, close to the other shops, convenient location, parking and understanding customer needs, as well the property is clean and service is provided in a timely fashion. (KLAYSUNG, 2016)

Organized programs of the spa are average important for the respondents. From the actually serviced programs, family and children events were found as the most attractive ones. In the selected spa several night baths are organized annually, the main target age group of these events are between 18-30 and 31-45. According to the respondents, healthcare services of the spa are used the most, but new, other services are welcomed as well.

The deterministic target group of health tourism is guests with actual diseases and medical problems, though, wellness is attractive for followers of healthy lifestyle and susceptible guests to prevention (BIRO et. al. 2018). However, our results show that age groups under 45 are less health-conscious. Age group above 46 is motivated to prevention and cure, there was no significant difference in coherence with this motivation in case of other age groups. Under 45 gaining experience, relaxing, social life and leisure activities showed strong relationship. Due to the strengthen of wellness orientation during the last decade - which involves the listed motivations
-, there is a need and worth to expand spa services to maintain market competence. Prevention, relaxation are directions of development in case of the examined spa as well aiming to meet with the demands and motivations of every generation. This attraction is boosted by organised programs too.

The main target group - elder age group - should be kept in mind, because these guests have an important role in the life of spas and baths. The role of senior visitors probably will increase in the following decades. Offering services for this target group may give a solution to the seasonal variety and inequality because musculoskeletal abnormalities cannot be adapted to any season, medication and cure in covered pools are offered during whole year. Based on our research, the secret of long-term success of the selected spa is forming a "relaxation and medication" destination, which is adapted to today's requirements, considers multi-generations, offers attractive services and fulfils health tourism needs and demands for leisure activities. The main benefit of this research for the management of the bath the knowledge of the critical points of decisions.

\section{REFERENCES}

Aquaprofit Rt. (2007) Országos egészségturizmus fejlesztési stratégia. http://2010-2014.kormany.hu/download/b/8e/20000/ Egeszsegturizmusstrategia.pdf\#!DocumentBrowse Approached: 2019.03.22.

Bede B. (2014): Gyógyfürdők és gyógyszállók Magyarországon. Corvina Kiadó Kft., Budapest.

Bender T. (2014): Balneoterápia és hidroterápia. Medicina Könyvkiadó Zrt., Budapest.

Bíró M., Müller A. (2017): Aktív pihenés, rekreáció = Active relaxation, recreation. In: Dobos, Anna; Mika, János Természeti és kultúrtörténeti értékek Eger térségében = Natural and cultural heritage in the Eger Region. Eger, Magyarország : Líceum Kiadó, (2017) pp. 128-130.

Biró M., Lenténé P.A., Dobay B., Müller A. (2018):Az Északalföldi fürdők szerepe a wellness turizmusban.In: Balogh, László (szerk.) Fókuszban az egészség.Debrecen, Magyarország : Debreceni Egyetem Sporttudományi Koordinációs Intézet, (2018) pp. 38-49. , 12 p.

Boros Sz., Mondok A., Várhelyi T (2012) Az egészségturizmus szolgáltatásai és menedzsmentje. Szolnoki Főiskola https://gk.unineumann.hu/images/tv-tanszek/tantargyi-segedanyagok/boros mondok_varhelyi_egeszsegturizmus_jegyzet.pdf (Kaposvári Egyetem Gazdaságtudományi Kar Kereskedelmi és Marketing Tanszék; Approached: 2019.02.07.

Cseke L. (1982): Észak-Magyarország Gyógyfürdôi és fürdôi. Panoráma Kiadó, Budapest.

Falus I. És Ollé J. (2000): Statisztikai módszerek pedagógusok számára. Okker Kiadó, Budapest.

Gáspár E. (2009): Magyarország geotermikus adottságai termálkarszt gyógyvizek Magyarországon. Miskolci Egyetem Közleményei I. sorozat 181-188.old.

Győri F., Hézsôné B. A., Kiss, Lehmann D. A. Meszlényi L. E. Balogh L. (2013) Szegedi Tudományegyetem, A wellness turizmus. http://www.jgypk.hu/tamop13e/tananyag_html/ 
wellness/a_wellnessturizmus.html Approached: 2018.10.07.

Kerényi, E ; Müller, A ; Szabó, R ; Mosonyi, A (2009): Analysis of Agárd, Komárom and Papa's Thermal and Experiences bath according the guest's satisfaction. In: Kerényi, Erika (szerk.) Egészségügyi marketing és telekommunikáció. Mátraháza, Magyarország (2009) pp. 56-67.

Könyves E., Müller A., Ködmön J. (2013): Az egészségturizmus fókuszai. Debreceni Egyetemi Kiadó, Debrecen.

KSH: Központi Statisztikai Hivatal (2017) Idősoros éves adatok http://www.ksh.hu/docs/hun/xstadat/xstadat_eves/i_fur001a. html? down=4106; Approached: 2019. 01. 27

Klaysung Chutima (2016): Behaviors and Factors Affecting the Selection of Spa Services among Consumers in Amphawa, Samut, Songkhram, Thailand. World Academy of Science, Engineering and Technology International Journal of Social and Business Sciences Vol: 10, no:12, 2016 3897-3901.

Lőke Zs., Kovács E., Bacsi Zs.(2018): Assessment of service quality and consumer satisfaction in a hungarian spa. DETUROPE - The Central European Journal of regional development and tourism. Vol. 10 Issue 22018 124-146.

Mező F., Kovács T. (2013): Az egészségturizmus az Észak-alföldi régió lehetséges kitörési pontja. Turizmus Bulletin, 14. 4-11

Michalkó G., Rácz T. (2011): Egészségturizmus és életminőség Magyarországon. MTA Földrajztudományi Kutatóintézet, Budapest.

Mosonyi A, Lengyel A., Müller A. (2013): Branding potential of spas in the Northern Plain and the Mid-Transdanubian Regions. APSTRACT - Applied Studies in Agribusiness and Commerce 7 : 4-5 pp. 97-101. , 5 p. (2013)

Müller, A, Könyves, E (2006): Az egészségturizmus lehetôségei az Észak-alföldi régióban. Acta Academiae Paedagogicae Agriensis Nova Series: Sectio Sport 33 pp. 132-143.

Müller A. (2018): Health tourism in Hungary.In: Jaromír, Šimonek; Beáta, Dobay (szerk.) Sport science in motion : proceedings from the scientific conference. Športová veda v pohybe: recenzovaný zborník vedeckých a odborných prác z konferencie. Mozgásban a sporttudomány: válogatott tanulmányok a konferenciáról.Komárno, Szlovákia : Univerzita J. Selyeho, (2018) pp. 8-15.

Müller A., Barcsák B., Boda E. J. (2016): Health tourism the cavebath of Miskolctapolca.In: György, Juhász; Enikô, Korcsmáros; Erika, Huszárik (szerk.) Korszerû szemlélet a tudományban és az oktatásban. Gazdaságtudományi szekció : Zborník medzinárodnej vedeckej konferencie Univerzity J. Selyeho - 2016 „Súcasné aspekty vedy a vzdelávania” . Sekcie ekonomických vied Komárno, Szlovákia : Selye János Egyetem, (2016) pp. 233-245. , 13 p.

Müller A., Szabó R. (2009): Analysis of Agárd, Komárom and Papa's Thermal bath, According the Guest's satisfaction. Acta Academiae Paedagogicae Agriensis Nova Series: Sectio Sport 36. pp. 89-101.

MTÜ: Magyar Turisztikai Ügynökség (2018) Turisztikai termékek - Egésszégturizmus https://mtu.gov.hu/cikkek/egeszsegturizmus; 2018.05.22)

ÖTM: Önkormányzati és Területfejlesztési Minisztérium Turisztikai Szakállamtitkársága (2007): Az Országos egészségturizmus fejlesztési stratégia. Turizmus Bulletin. XI/4. szám. 55-56. old.
Pintér T. (2013): Gyógykúrák új vizeken. Turizmus panoráma, 12. $44-48$

Reiczigel J., Harnos A., Solymosi N. (2014): Biostatisztika nem statisztikusoknak. Pars Kft., Nagykovácsi.

Szabó Z. (2015): A gyógyvízre alapozott fürdővárosfejlesztések lehetőségei. Kaposvári Egyetem Gazdaságtudományi kar, Kaposvár

Sziva I. (2010): Öntsünk tiszta vizet... Az egészségturizmus fogalmi lehatárolása és trendjeinek válogatott bibliográfiája. Turizmus Bulletin, 14. 73-76.

Vildová E., Martincik D., Tluchor J., Jakubikova D. (2015): Measuring customer satisfaction and loyalty in spa companies. Marketing and Trade 1. XVIII, 2015 151-167. 
